\title{
Metabolic Changes in Seed Embryos of Hypoxia-Tolerant Rice and Hypoxia-Sensitive Barley at the Onset of Germination
}

\author{
Jayamini Jayawardhane ${ }^{1,2, *}$, M. K. Pabasari S. Wijesinghe ${ }^{1,3}$, Natalia V. Bykova ${ }^{3}$ and Abir U. Igamberdiev $1, * \mathbb{C}$ \\ 1 Department of Biology, Memorial University of Newfoundland, St. John's, NL A1C 5S7, Canada; \\ mkpswijesing@mun.ca \\ 2 Department of Botany, Faculty of Science, University of British Columbia, Vancouver, BC V6T 1Z4, Canada \\ 3 Morden Research and Development Centre, Agriculture and Agri-Food Canada, \\ Morden, MB R6M 1Y5, Canada; natalia.bykova@agr.gc.ca \\ * Correspondence: jjayawardhan@mun.ca (J.J.); igamberdiev@mun.ca (A.U.I.)
}

\section{check for}

updates

Citation: Jayawardhane, J.; Wijesinghe, M.K.P.S.; Bykova, N.V.; Igamberdiev, A.U. Metabolic Changes in Seed Embryos of Hypoxia-Tolerant Rice and Hypoxia-Sensitive Barley at the Onset of Germination. Plants 2021 10, 2456. https://doi.org/10.3390/ plants10112456

Academic Editors: Beata Prabucka, Mateusz Labudda, Marta Gietler, Justyna Fidler and Małgorzata Nykiel

Received: 30 September 2021 Accepted: 11 November 2021 Published: 14 November 2021

Publisher's Note: MDPI stays neutral with regard to jurisdictional claims in published maps and institutional affiliations.

Copyright: (c) 2021 by the authors. Licensee MDPI, Basel, Switzerland. This article is an open access article distributed under the terms and conditions of the Creative Commons Attribution (CC BY) license (https:/ / creativecommons.org/licenses/by/ $4.0 /)$.

\begin{abstract}
Rice (Oryza sativa L.) and barley (Hordeum vulgare L.) are the cereal species differing in tolerance to oxygen deficiency. To understand metabolic differences determining the sensitivity to low oxygen, we germinated rice and barley seeds and studied changes in the levels of reactive oxygen species (ROS) and reactive nitrogen species (RNS), activities of the enzymes involved in their scavenging, and measured cell damage parameters. The results show that alcohol dehydrogenase activity was higher in rice than in barley embryos providing efficient anaerobic fermentation. Nitric oxide (NO) levels were also higher in rice embryos indicating higher NO turnover. Both fermentation and NO turnover can explain higher ATP/ADP ratio values in rice embryos as compared to barley. Rice embryos were characterized by higher activity of $S$-nitrosoglutathione reductase than in barley and a higher level of free thiols in proteins. The activities of antioxidant enzymes (superoxide dismutase, ascorbate peroxidase, monodehydroascorbate reductase, dehydroascorbate reductase) in imbibed embryos were higher in rice than in barley, which corresponded to the reduced levels of ROS, malonic dialdehyde and electrolyte leakage. The observed differences in metabolic changes in embryos of the two cereal species differing in tolerance to hypoxia can partly explain the adaptation of rice to low oxygen environments.
\end{abstract}

Keywords: Oryza sativa; Hordeum vulgare; hypoxia tolerance; nitric oxide; imbibition; reactive oxygen species; ATP/ADP ratio

\section{Introduction}

Rice (Oryza sativa L.) and barley (Hordeum vulgare L.) are economically important cereal crops. Apart from being the staple foods in many countries, rice and barley are also ideal plant models for studying monocot seed germination because of the availability of genomic resources with annotated reference genomes and well-studied physiological, morphological and metabolic traits [1,2]. Rice is an anoxia/hypoxia tolerant species, while barley is hypoxia/anoxia intolerant [3], which makes these species important for elucidating the genetic, physiological and biochemical background of hypoxia tolerance. Since the germinating seeds of all cereals and many other plants are highly hypoxic upon imbibition and before radicle protrusion [4], we used rice and barley as contrasting plant species to study the differences in their metabolism in order to explain the metabolic basis of coping with hypoxia tolerance at the early stages of germination.

Seed germination is a vital stage in the plant life cycle, and it begins with seed rehydration and imbibition [5]. In general, the germination process can be distinguished by three major phases, which include rapid water uptake by a dry seed upon imbibition (phase I), reactivation of metabolism (phase II), and radicle protrusion (phase III) [4]. The second phase is the most critical stage where important physiological and biochemical processes that initiate the germination process reactivate [6]. Due to imbibition, the cell 
wall enlarges, the seed coat becomes softened [7], and the water availability directs the enzymatic hydrolysis of proteins, lipids and carbohydrates, and the transportation of metabolites [8].

Seed germination and dormancy are under the control of both genetic and biochemical processes [9]. Weakening of the endosperm during germination via by $\alpha$-xylosidase activity, biosynthesis of xyloglucan in the endosperm, arrangement of cutin coat in the endosperm-testa interface play critical roles in determining dormancy and germination [9]. Some structures of the seed, such as seed coat (or testa), act as a physical barrier for gas exchange [10]. Due to the resumption of respiratory activity following imbibition, the oxygen content in the seed tissue is rapidly diminished (reviewed in [11]). Therefore, the supply of the oxygen through the seed coat to the embryo becomes limited, which generates the hypoxic environment in the seed [12]. Consequently, aerobic respiration in the seed is suppressed and anaerobic respiration is developed to maintain the energy status in cells [13]. Initiation of the fermentation process under hypoxic condition is considered as an adaptive mechanism for ATP synthesis $[14,15]$. The increased ethanol fermentation in seeds is linked with oxygen deprivation and is catalyzed primarily with the participation of alcohol dehydrogenase (ADH) $[14,16]$. Consequently, the ATP level and energy charge inside seeds remain high during early germination $[17,18]$.

Moreover, the balance between reactive nitrogen species (RNS) that include nitric oxide (NO) and reactive oxygen species (ROS), acting as the important signaling substances under stress, plays a crucial role in breaking dormancy of seeds and induction of germination [19-23]. Imbibition induces the formation of ROS and RNS [21,24] and leads to the changes in thiol redox-sensitive seed proteome $[25,26]$. Hypoxic environment within the seed triggers the production of NO under the seed coat [27]. ROS are formed during the restarting of metabolism by the increased oxidative processes leading to the activation of electron transport, in particular at the levels of mitochondrial electron transport chain, of the plasma membrane NADPH oxidase, xanthine oxidase and peroxidases as part of an oxidative burst during rehydration [28]. Antioxidant systems and proteins that scavenge reactive radicals and $\mathrm{NO}$ reduce oxidative stress damage in seeds to prevent loss of germination capacity $[29,30]$ and these biochemical events are activated immediately upon rehydration [31-35].

In this study, we evaluated metabolic differences that control the sensitivity to oxygen deficiency in germinating rice and barley seeds. Changes in the levels of ROS and RNS, in activities of the enzymes involved in their generation and scavenging were determined, and parameters measuring cell damage such as malonic dialdehyde and electrolyte leakage were assessed. The observed differences in metabolic responses in embryos of the cultivars of two cereal species differing in tolerance to hypoxia are discussed in relation to the development of mechanisms of metabolic adjustments to low oxygen conditions occurring in germinating seeds.

\section{Results}

\subsection{Germination Rates of Rice and Barley Seeds}

Barley seeds started radicle protrusion at $15 \mathrm{~h}$ while in rice the protrusion of radicle was delayed until $48 \mathrm{~h}$ of post-imbibition. Both species showed a similar germination percentage at the end of five days after imbibition (barley 97\%, rice 93\%). However, the rate of germination in rice at the initial stage was lower than in barley. After three days, a similar germination percentage was reached in both species, and was comparable until the end of five days of germination assay (Figure 1).

\subsection{Alcohol Dehydrogenase Activity and the Level of Adenylates during Germination}

Embryonic ATP content exhibited the initial fluctuation in both species (Figure 2A). In barley, the peak of ATP level was observed at $9 \mathrm{~h}$ from the start of imbibition while in rice at $15 \mathrm{~h}$. The following decline was sharp in barley and smoother in rice. Further increase of ATP content by $48 \mathrm{~h}$ was pronounced in barley but was not observed in rice (Figure $2 \mathrm{~A}$ ). 


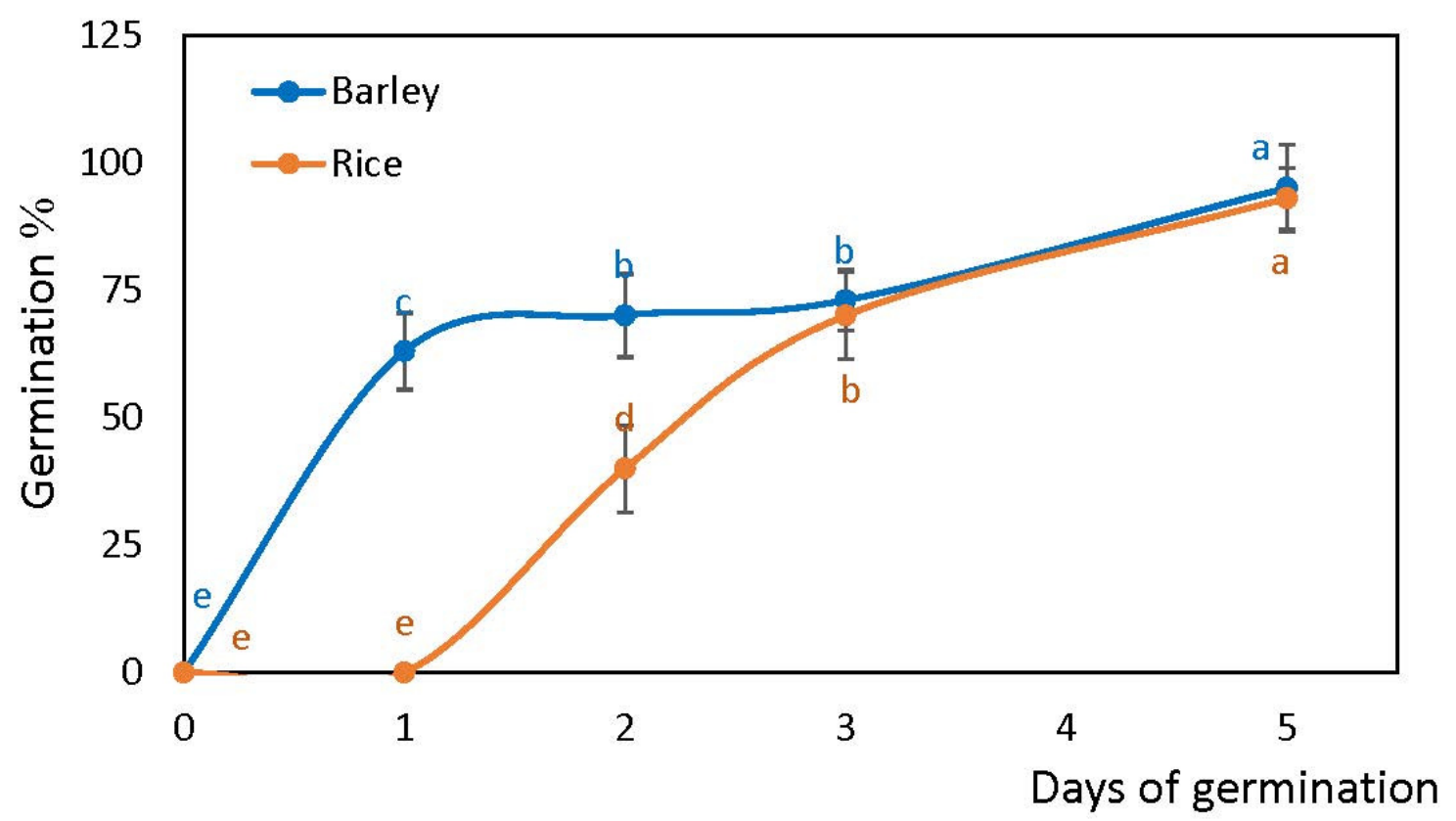

Figure 1. Germination of rice and barley seeds. Germination rates of two species within five days of imbibition. Vertical bars represent standard deviations $(n=3)$. Different letters indicate significant differences between the two species and the time points at $p<0.05$, (one-way ANOVA test, Tukey comparison).
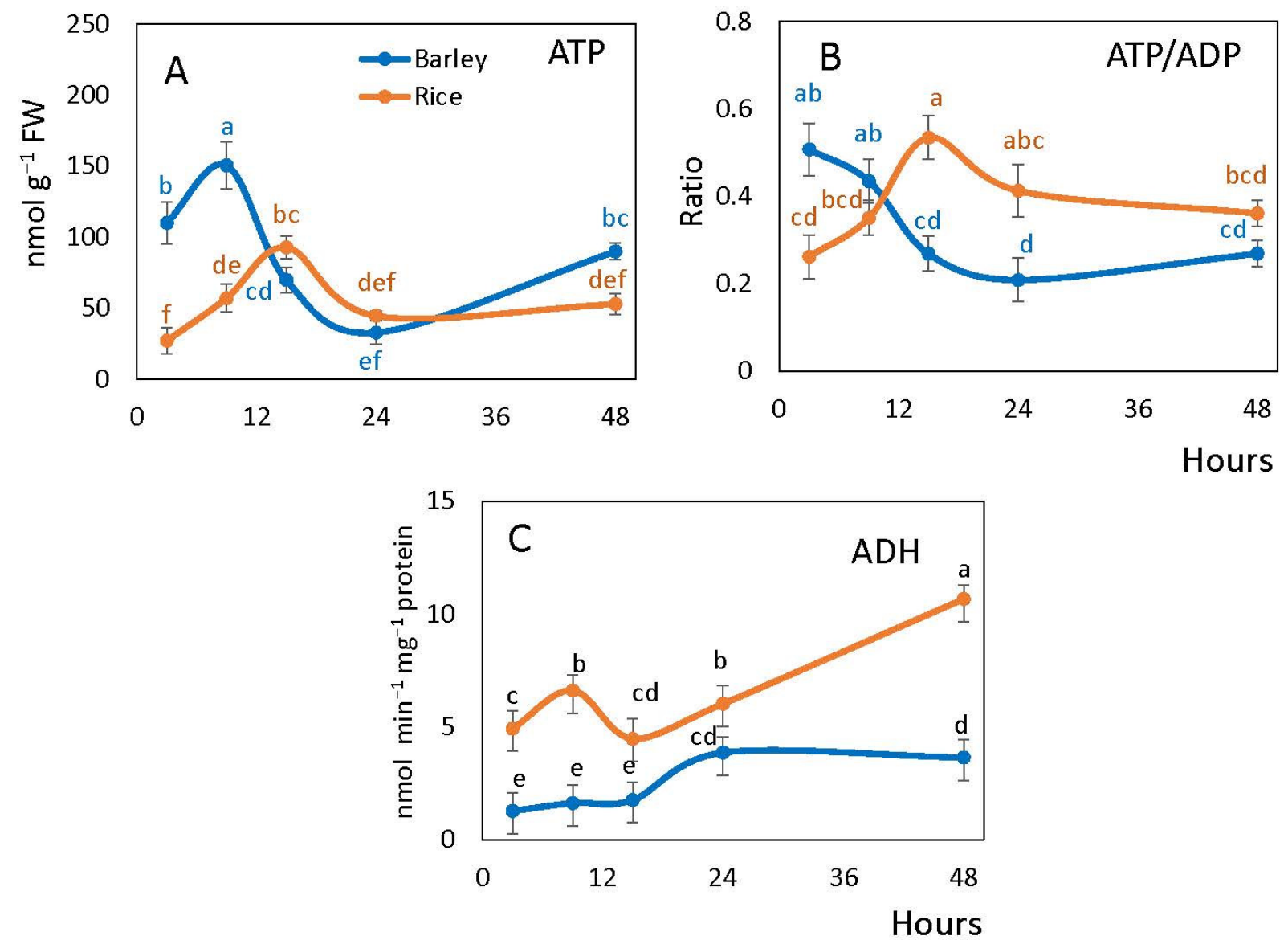

Figure 2. Total ATP (A), ATP/ADP ratio (B) and ADH activity (C) in barley and rice seeds following imbibition. Vertical bars represent standard deviations $(n=3)$. Different letters indicate significant differences between the two species and the time points at $p<0.05$, (one-way ANOVA test, Tukey comparison). 
The ATP / ADP ratio generally followed a similar pattern to the ATP content in rice, but in barley seed embryos it gradually declined upon imbibition and then stabilized. In rice embryos, the ATP / ADP ratio increased from the values of $\sim 0.2$ lower than in barley at $3 \mathrm{~h}$ peaking at $\sim 0.25$ higher than in barley at $15 \mathrm{~h}$, and then slightly decreased (Figure $2 \mathrm{~B}$ ).

$\mathrm{ADH}$ activity in the embryos was significantly higher in rice than barley. In rice, it markedly increased at $9 \mathrm{~h}$ after imbibition followed by a drop at $15 \mathrm{~h}$, after which it continued to increase significantly. On the contrary, ADH activity in barley remained constant for $15 \mathrm{~h}$ and then increased by $24 \mathrm{~h}$ (Figure 2C).

\subsection{Nitric Oxide, Free Thiols, S-Nitrosoglutathione Reductase and S-Nitrosylation}

$\mathrm{NO}$ content in embryos during germination remained higher in rice than in barley throughout the whole time of observation, the difference was not significant only at $15 \mathrm{~h}$. It decreased until $15 \mathrm{~h}$ of imbibition in rice and until $9 \mathrm{~h}$ in barley, and then continuously increased (Figure 3A).
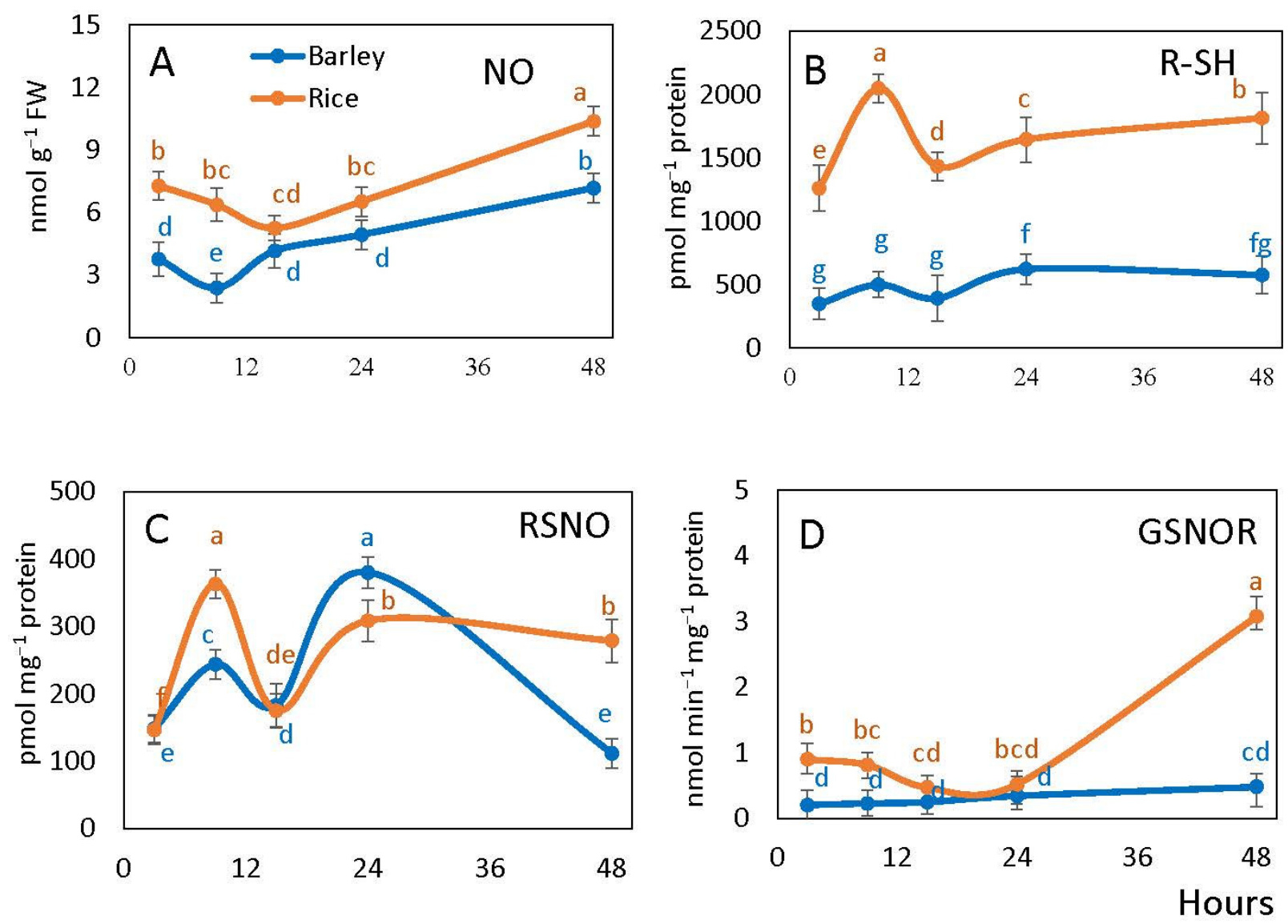

Figure 3. Levels of NO (A), free thiols (R-SH) (B), S-nitrosylation (RSNO) (C) and S-nitrosoglutathione (GSNOR) activity (D) in barley and rice embryos following imbibition. Vertical bars represent standard deviations $(n=3)$. Different letters indicate significant differences between the two species and the time points at $p<0.05$, (one-way ANOVA test, Tukey comparison).

Free thiol (RSH) content of embryos was essentially higher in rice embryos than in barley embryos. In rice, the content of thiols exhibited an increase at $9 \mathrm{~h}$ after imbibition followed by a decrease at $15 \mathrm{~h}$ and further increase to $24 \mathrm{~h}$. In barley, only a slight increase was observed from 15 to $24 \mathrm{~h}$. Between 24 to $48 \mathrm{~h}$ of imbibition, the measured R-SH content remained stable in barley and slightly increased in rice (Figure 3B).

The content of $S$-nitrosylated (RSNO) groups exhibited significant fluctuations over time points in both species. It increased sharply in rice and more moderately in barley at $9 \mathrm{~h}$, and then decreased by $15 \mathrm{~h}$ of imbibition. A further increase was observed at one 
day of imbibition, after which RSNO level remained stable in rice and decreased in barley (Figure 3C).

S-nitrosoglutathione reductase (GSNOR) activity of seed embryo was higher in rice than in barley in the first $9 \mathrm{~h}$ and by $48 \mathrm{~h}$ after imbibition. The activity level was stable in barley during the entire period of observation, while in rice it decreased by $15 \mathrm{~h}$ and then increased sharply from 24 to $48 \mathrm{~h}$ (Figure 3D).

\subsection{Reactive Oxygen Species, Lipid Peroxidation and Electrolyte Leakage in Rice and Barley Seeds}

The level of hydrogen peroxide $\left(\mathrm{H}_{2} \mathrm{O}_{2}\right)$ in embryo was significantly higher in barley than in rice during all periods of observation, except the $15 \mathrm{~h}$ point. In barley, apart from the steep decrease from 9 to $15 \mathrm{~h}$ corresponding to the time before radicle protrusion, the level remained constant and exceeded $\mathrm{H}_{2} \mathrm{O}_{2}$ level in rice by 2-4 times. Rice embryo showed a generally stable $\mathrm{H}_{2} \mathrm{O}_{2}$ level until $24 \mathrm{~h}$, followed by the increase to $48 \mathrm{~h}$ (Figure $4 \mathrm{~A}$ ).
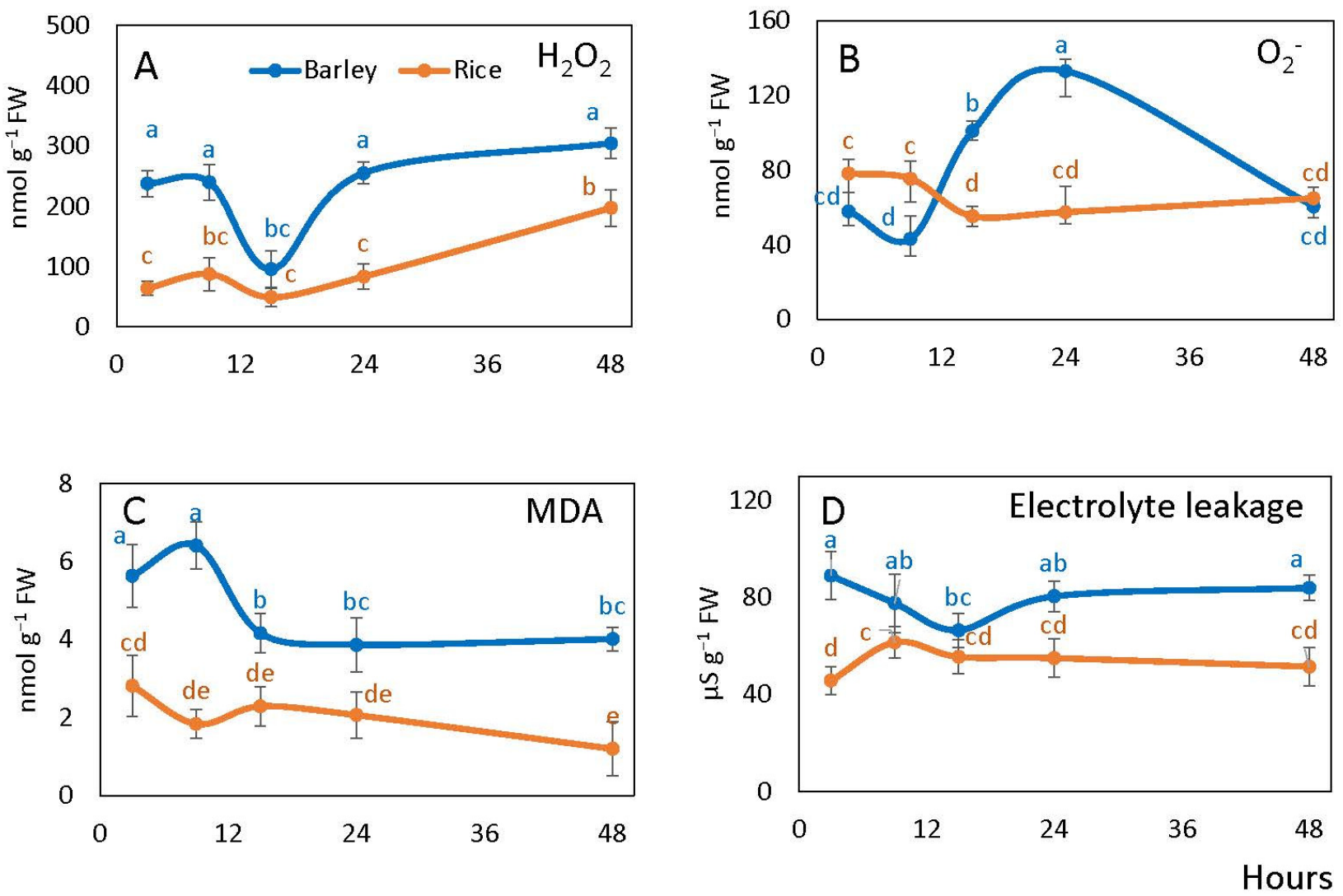

Figure 4. Barley and rice seed embryonic hydrogen peroxide $\left(\mathrm{H}_{2} \mathrm{O}_{2}\right)(\mathbf{A})$, superoxide anion $(\mathbf{B})$, lipid peroxidation in terms of MDA (C) and seed electrolyte leakage (D) following imbibition. Vertical bars represent standard deviations $(n=3)$. Different letters indicate significant differences between the two species and the time points at $p<0.05$, (one-way ANOVA test, Tukey comparison).

Embryonic superoxide anion content in rice was slightly higher than in barley at $9 \mathrm{~h}$ after imbibition, then decreased by $15 \mathrm{~h}$ and did not change significantly in the subsequent hours. In barley, superoxide levels increased by $15 \mathrm{~h}$ peaking at $24 \mathrm{~h}$ at the levels threefold higher than at the beginning of imbibition, followed by further decline to $48 \mathrm{~h}$ (Figure $4 \mathrm{~B}$ ).

Malondialdehyde (MDA) levels in the embryos remained significantly (2-3 times) higher in barley than in rice after imbibition being the highest at 3 and $9 \mathrm{~h}$ of imbibition (before radicle protrusion). MDA levels in rice did not exhibit significant changes over the whole period (Figure 4C).

Electrolyte leakage of germinating barley seeds was also significantly higher in barley than in rice during almost all period of observation (except the $15 \mathrm{~h}$ point). The levels 
slightly declined in barley until $15 \mathrm{~h}$ and then slightly increased to $48 \mathrm{~h}$. In rice seeds, the changes in the level of electrolyte leakage were statistically insignificant over the germination period tested except the initial slight increase (Figure 4D).

\subsection{Antioxidant Enzyme Activities in Rice and Barley Seeds}

All studied antioxidant enzymes except catalase exhibited higher activity in rice than in barley (Figure 5). SOD activity increased sharply in rice embryo during germination reaching 5-10 times higher values than in barley where it changed only slightly with the two-fold increase by $24 \mathrm{~h}$ (after radicle protrusion) (Figure 5A). Catalase activity strongly increased in barley embryos at the onset of germination, while in rice embryos it was always lower and increased only at $24 \mathrm{~h}$ of imbibition (Figure 5B).
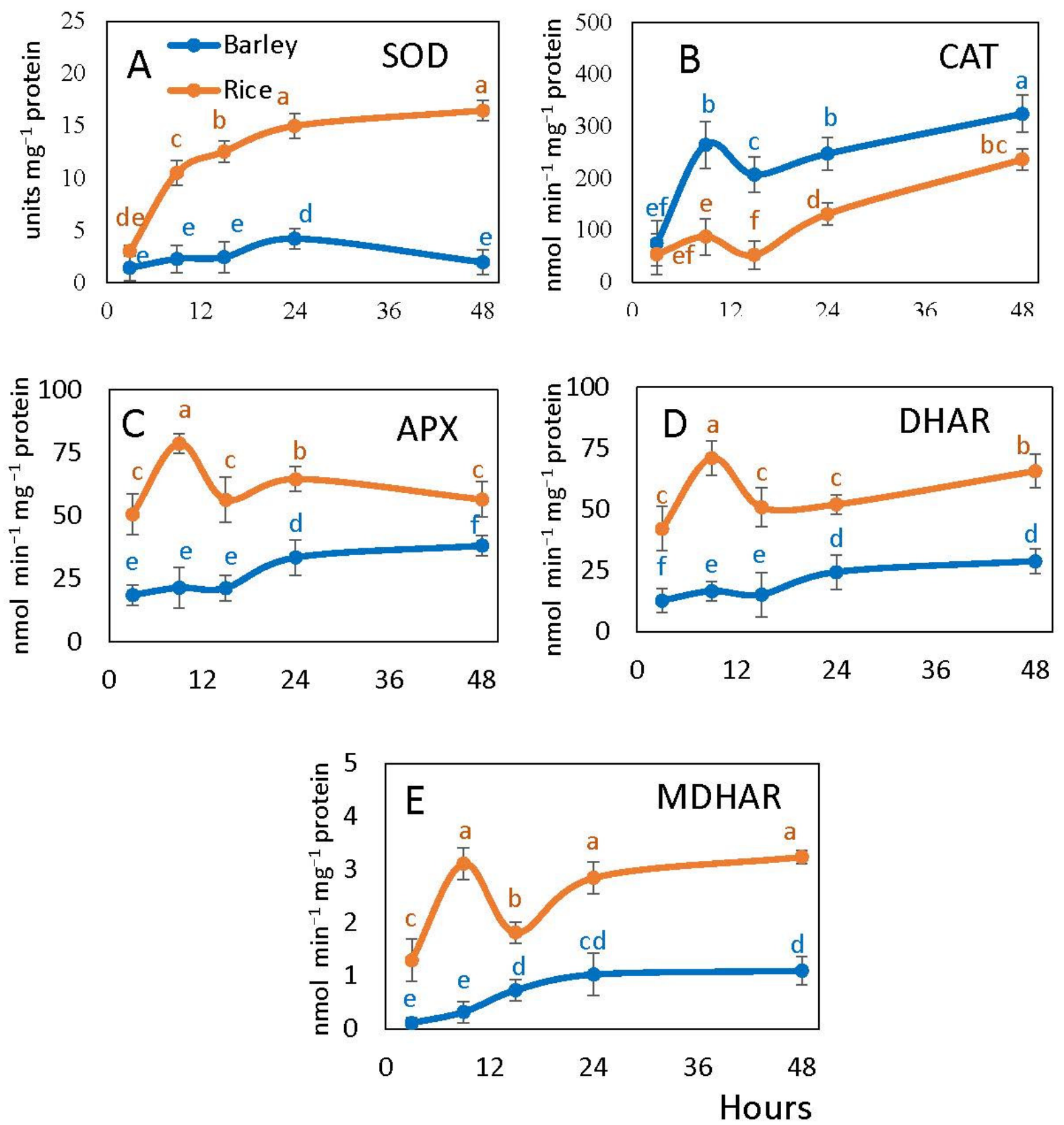

Figure 5. Embryonic antioxidant enzyme activities of barley and rice seeds following imbibition: superoxide dismutase (SOD) (A), catalase (CAT) (B), ascorbate peroxidase (APX) (C), dehydroascorbate reductase (DHAR) (D), monodehydroascorbate reductase (MDHAR) (E). Vertical bars represent standard deviations $(n=3)$. Different letters indicate significant differences between the two species and the time points at $p<0.05$, (one-way ANOVA test, Tukey comparison). 
APX, MDHAR and DHAR activities were consistently higher in rice than in barley exhibiting an increase at $9 \mathrm{~h}$ and decrease at $15 \mathrm{~h}$. In barley embryos, they were lower with a smooth increase of APX and DHAR by $24 \mathrm{~h}$ (upon radicle protrusion) and the earlier continuous increase of MDHAR (Figure 5C-E).

\section{Discussion}

\subsection{Seed Germination Phases and Hypoxic Conditions under Seed Coat}

Seed imbibition triggers many biochemical and cellular processes associated with germination $[6,36]$. As water is taken up by the dry seed, it triggers the transition of seed to germination which completes with the emergence of embryonic radicle tissues from the seed coat [8]. Germination of cereals is controlled by complex signalling networks including both internal and external cues [23]. Phytohormones such as ABA and GA act as the hubs that connect internal and external signals, controlling germination antagonistically, whereas other phytohormones, carbohydrates, ROS, NO, microRNAs, light, and temperature also affect germination at the transcriptional, translational, and post-translational levels [23]. Bewley [4] observed radicle protrusion in rice at $50 \mathrm{~h}$ of imbibition and Ma et al. [35] observed radicle protrusion in barley at $12-15 \mathrm{~h}$ of imbibition. Our results demonstrate that barley seeds started radicle protrusion at $15 \mathrm{~h}$ of imbibition, while in rice it only happened between 24 and $48 \mathrm{~h}$ after onset of imbibition (Figure 1).

According to Gruwel et al. [37], barley seeds hydrate rapidly during very early imbibition and the absorbed water is mainly confined to the embryo tissue. A triphasic model was introduced to reflect the increase of total water content during germination [4]. During the first $20 \mathrm{~h}$ of imbibition (Phase I), rice seeds increased in weight rapidly without significant morphological changes [4]. Phase II showed a stable plateau until $50 \mathrm{~h}$ where the coleoptiles elongated [4]. Another rapid water uptake stage and radicle protrusion were shown to take place in Phase III [38].

While Phase I is characterized by the dramatic increase in respiration rates in seeds, the internal oxygen concentration due to the low permeability of seed coat is rapidly depleted $[4,11]$. The seed becomes hypoxic at Phase II for a prolonged period of time in rice, while in barley this phase is significantly shorter. A longer duration of the hypoxic phase in rice means the persistence of efficient anaerobic metabolism in this plant, while in barley, lower resistance to oxygen deficiency requires a fast completion of this phase and accelerated transition to Phase III initiated by radicle protrusion. From this point of view, the comparison of metabolism in rice and barley during seed germination can reveal essential metabolic differences at this stage related to hypoxia sensitivity in plants. Below we discuss these differences in relation to fermentation, nitric oxide metabolism, production and scavenging of ROS and RNS in the overall context of energy metabolism of the germinating seeds.

\subsection{Respiration and Energy Availability in the Embryos of Imbibed Seeds}

Due to a rapid depletion of oxygen in seed tissues upon imbibition, oxidative respiration becomes limited, resulting in the depleted energy status of early germinating seeds [39-41]. According to He et al. [42], aerobic respiration in rice seeds is quite low during the first $48 \mathrm{~h}$ of imbibition due to the lack of functional mitochondria. However, seed ATP levels and energy charge remain elevated because of the glycolytic fermentation and/or other adaptive and alternative mechanisms for energy generation [17,18,43]. Anaerobic respiration pathways, such as fermentation, might be the main source of energy at the early stage of germination of rice seeds [38,44]. Fermentation in terms of ADH activity was higher in rice than in barley and it increased continuously in the first nine hours and then from $15 \mathrm{~h}$ towards $48 \mathrm{~h}$ when all rice seeds become germinated (Figure 2C). This indicates more efficient anaerobic metabolism in rice than in barley and explains the observed fact that the germination of rice seeds can take more time, during which oxygen becomes almost fully depleted. During this time (starting from $15 \mathrm{~h}$ ), rice seeds can maintain higher ATP / ADP ratio than barley seeds despite of the delayed radicle protrusion. At $24 \mathrm{~h}$ of 
imbibition, when most barley seeds are germinated and rice seeds are not, the ATP/ADP ratio remains higher in rice. In addition to the glycolytic fermentation, alternative pathways such as the phytoglobin-NO cycle, can contribute to the maintenance of high energy state under the conditions of hypoxia [45]. Further, phytoglobin (Pgb1) gene expression is essential to maintain redox and energy balance before radicle protrusion, when seeds experience low internal oxygen concentration [46].

\subsection{Nitric Oxide and ROS Scavengers in Embryo of Imbibed Seeds}

Seeds produce ROS such as $\mathrm{H}_{2} \mathrm{O}_{2}, \mathrm{O}_{2}{ }^{-}$, and hydroxyl radicals, and $\mathrm{RNS}$, such as $\mathrm{NO}$, during imbibition [21,24,47-49]. ATP production under the conditions of oxygen deficiency can be associated not only with the glycolytic fermentation but also with the phytoglobin$\mathrm{NO}$ cycle [50]. NO is scavenged by class 1 phytoglobin that is expressed within $2 \mathrm{~h}$ after imbibition of seeds $[17,45,51-53]$. Our results revealed that the NO level was higher in rice than in barley embryo (Figure 3A), suggesting that the phytoglobin-NO cycle could be more active in rice, and a higher ATP/ADP ratio in rice than in barley at 15-24 h might be related to the activity of this cycle. For rice, it has been shown that the phytoglobin-NO cycle and the mitochondrial alternative oxidase play a vital role in anaerobic germination and growth of deep-water rice [54]. A sharper decrease of RSNO (which mostly refers to $S$-nitrosoglutathione) in rice than in barley (Figure 3C) after $9 \mathrm{~h}$ may be associated with the direction of NO towards nitrate formation in the phytoglobin-NO cycle instead of $S$-nitrosylation of glutathione and proteins. S-nitrosoglutathione is scavenged by GSNOR, which is the class III alcohol dehydrogenase having also the activity of formaldehyde dehydrogenase [55]. From the obtained values of RSNO levels, it can be concluded that a part of the produced $\mathrm{NO}$ goes to $S$-nitrosylation, and this process decreases in barley after radicle protrusion, while in rice seeds that protrude radicles later, $S$-nitrosylation remains stable at $24-48 \mathrm{~h}$ due to the increased GSNOR activity (Figure 3D). More efficient $\mathrm{NO}$ scavenging in rice may explain the observation that free $\mathrm{SH}$ groups are present at a higher level than in barley (Figure 3B).

\subsection{Reactive Oxygen Species and Antioxidant System in Seed Embryo during Germination}

Imbibition processes that induce ROS formation (mostly $\mathrm{H}_{2} \mathrm{O}_{2}$ ) facilitate dormancy decay and promote germination [56,57]. The balance between ROS-producing and ROSscavenging systems plays a key role in seed germination and dormancy alleviation [21]. The ability of seeds to germinate is linked with the accumulation of a critical level of $\mathrm{H}_{2} \mathrm{O}_{2}$ [26]. Our results show higher $\mathrm{H}_{2} \mathrm{O}_{2}$ levels in barley seed embryo than in rice (equaling only at $15 \mathrm{~h}$ ) and higher superoxide levels at 15-24 h, which correlates to the earlier onset of germination in barley seeds (Figure 4A,B). A lower NO level in barley embryo may be associated with the involvement of ROS in NO scavenging [22]. Higher ROS levels in barley embryos can also explain the increased values of cell damages in terms of lipid peroxidation and electrolyte leakages (Figure 4C,D). ROS are scavenged by the efficient antioxidant systems [29,30,33], which are activated immediately upon rehydration [31,32]. Lower ROS levels in rice embryos can be explained by higher activities of most antioxidant enzymes (except catalase) (Figure 5). Our results demonstrate that in rice embryos, APX, having higher affinity to $\mathrm{H}_{2} \mathrm{O}_{2}$ [58], is more involved in its scavenging than catalase as compared to barley. While in our study generally lower ROS levels correspond to a slower germination in rice than in barley, this correlation is comparable to the postulation of "oxidative window" for dry seeds resulting in seed dormancy decay and aging [20,59]. Germinating rice seeds are characterized by a lower level of cell damage, higher fermentation and NO turnover rates and higher ATP/ADP ratios. This results in the germination process in rice being less susceptible to stress factors as compared to barley, including the ability to germinate anaerobically. 


\section{Materials and Methods}

\subsection{Seed Germination and Isolation of Embryos}

Barley (Hordeum vulgare L. cv. Harrington) and rice (Oryza sativa L. ssp. indica, cv. FR13A) seeds were surface sterilized with $10 \% \mathrm{NaOCl}$ and washed three times with autoclaved distilled water. Seeds were soaked in sterile deionized water on filter papers in Petri dishes at $25^{\circ} \mathrm{C}$ in darkness. The germination rate (total seeds germinated at end of trial/number of initial seeds $\times 100 \%$ ) was calculated according to Al-Mudaris [60].

We isolated fresh embryos of imbibed seeds at different hours following imbibition $(3,9,15,24,48 \mathrm{~h})$, froze them in liquid nitrogen and stored at $-80^{\circ} \mathrm{C}$ for further analysis to investigate the biochemical changes during germination within an extensive time course, from dry seeds to radicle protrusion.

All chemicals, unless indicated otherwise, were obtained from Sigma-Aldrich, St. Louis, MO, USA.

\subsection{Alcohol Dehydrogenase and Adenylate Ratios}

Alcohol dehydrogenase (ADH; EC 1.1.1.1) was measured according to Blandino et al. [61] in the direction of ethanol to acetaldehyde in $50 \mathrm{mM}$ Tris- $\mathrm{HCl}$ buffer, $\mathrm{pH} 8.0,150 \mathrm{mM}$ ethanol and $2 \mathrm{mM} \mathrm{NAD}^{+}$at $340 \mathrm{~nm}\left(\varepsilon=6.22 \mathrm{mM}^{-1} \mathrm{~cm}^{-1}\right)$.

ATP and ADP were extracted according to Joshi et al. [62] and Yuroff et al. [63] with minor modifications. The tissue powder was lysed on ice in $2.4 \mathrm{M}$ perchloric acid for $60 \mathrm{~min}$ and centrifuged for $5 \mathrm{~min}$ at $20,000 \times g$ at $4{ }^{\circ} \mathrm{C}$. The supernatant was neutralized with $4 \mathrm{M}$ $\mathrm{KOH}$, and the ratio ATP/ADP in the neutralized solution was determined according to the manufacturer's instructions using the EnzyLight ${ }^{\mathrm{TM}}$ ADP / ATP Ratio Bioluminescent Assay Kit (ELDT-100) (BioAssay Systems, Hayward, CA, USA). The content of ATP and ADP was determined using ATP and ADP standards.

\subsection{Nitric Oxide, Free Thiols, S-Nitrosylation and S-Nitrosoglutathione Reductase}

NO levels in seed embryos were measured by the hemoglobin $(\mathrm{Hb})$ method at $415 \mathrm{~nm}$ $\left(\varepsilon=131 \mathrm{mM}^{-1} \mathrm{~cm}^{-1}\right)$, as described by Murphy and Noack [64] and Ma et al. [35]. R-SH and RSNO were measured spectrophotometrically by reducing RSNO to R-SH in the presence of ascorbate and then assaying free thiol groups using 5,5'-dithio-bis (2-nitrobenzoic acid) (DTNB) at $412 \mathrm{~nm}[35,65]$. S-nitrosoglutatione reductase (GSNOR) activity was measured at $340 \mathrm{~nm}$ according to Sakamoto et al. [66]. Total soluble protein content was determined according to Bradford [67] using Bradford reagent (Sigma-Aldrich, St. Louis, MO, USA) and Bovine Serum Albumin (BSA) standard at $595 \mathrm{~nm}$.

\subsection{Hydrogen Peroxide, Electrolyte Leakage and Lipid Peroxidation}

$\mathrm{H}_{2} \mathrm{O}_{2}$ content was estimated according to Velikova et al. [68] with modifications. Fresh plant biomass $(600 \mathrm{mg})$ was homogenized in $3 \mathrm{~mL} 0.1 \%(w / v)$ TCA and centrifuged at $12,000 \times g$ for $20 \mathrm{~min}$ at $4{ }^{\circ} \mathrm{C}$. Supernatant $(300 \mu \mathrm{L})$ was mixed with $500 \mu \mathrm{L}$ of $2 \mathrm{M} \mathrm{KI}$ and $200 \mu \mathrm{L}$ of $10 \mathrm{mM}$ potassium phosphate buffer ( $\mathrm{pH}$ 7.0). The reaction mixture was incubated for $1 \mathrm{~h}$ in the dark at room temperature and the absorbance was recorded at $390 \mathrm{~nm}$. A standard curve was prepared to quantify the $\mathrm{H}_{2} \mathrm{O}_{2}$ content.

Electrolyte leakage from seeds at different hours of post-imbibition was measured according to Tammela et al. [69] with few modifications as described by Agarie et al. [70]. The seed coat was separated and $0.2 \mathrm{~g}$ seeds at different hours of post-imbibition was placed in $10 \mathrm{~mL}$ of deionized water. The electrical conductivity of the liquid phase was measured by using a handheld portable EC and TDS meter (E-1 TDS and EC meter, Aquasana Inc., Austin, TX, USA) after keeping the tubes with seeds for $24 \mathrm{~h}$ in dark conditions [70].

Lipid peroxidation was measured by tracing malondialdehyde (MDA, $\varepsilon=156 \mathrm{mM}^{-1}$ $\mathrm{cm}^{-1}$ ) content using thiobarbituric acid (TBA) method as described by Heath and Parker [71] 


\subsection{Superoxide Dismutase, Catalase and Ascorbate-Glutathione Cycle Enzymes}

Superoxide dismutase (SOD; EC 1.15.1.1) activity was assayed according to Beauchamp and Fridovich [72] by the inhibition of the photochemical reduction of nitroblue tetrazolium (NBT) at $560 \mathrm{~nm}$. The amount of enzyme causing 50\% inhibition of NBT reduction was used to calculate SOD activity. Catalase (EC 1.11.1.6) activity was measured according to

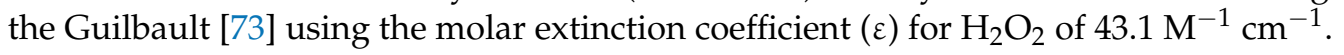

The enzymes of ascorbate-glutathione cycle were extracted and assayed as described by Ma et al. [35]. Ascorbate peroxidase (APX; EC 1.11.1.11) was estimated in $50 \mathrm{mM}$ potassium phosphate buffer ( $\mathrm{pH} 7.0$ ) containing $0.5 \mathrm{mM}$ sodium ascorbate and sample extract. The reaction was started by adding $\mathrm{H}_{2} \mathrm{O}_{2}$ (final concentration $1 \mathrm{mM}$ ) at $290 \mathrm{~nm}$ $\left(\varepsilon=2.8 \mathrm{mM}^{-1} \mathrm{~cm}^{-1}\right)$. Monodehydroascorbate reductase (MDHAR; EC 1.6.5.4) activity was measured in $50 \mathrm{mM}$ HEPES-KOH buffer ( $\mathrm{pH} 7.6$ ) containing $2.5 \mathrm{mM}$ ascorbate, $0.25 \mathrm{mM}$ $\mathrm{NADH}$, and the extract. The assay was initiated by adding $0.4 \mathrm{U} \mathrm{mL}-1$ of ascorbate oxidase and the reaction was monitored at $340 \mathrm{~nm}$ for $3 \min \left(\varepsilon=6.22 \mathrm{mM}^{-1} \mathrm{~cm}^{-1}\right)$. Dehydroascorbate reductase (DHAR; EC 1.8.5.1) activity was measured in $50 \mathrm{mM}$ HEPES$\mathrm{KOH}$ buffer (pH 7.0) containing 0.1 mM EDTA, $2.5 \mathrm{mM} \mathrm{GSH}$, and the extract. The reaction was initiated by adding freshly prepared dehydroascorbate (final concentration $0.8 \mathrm{mM}$ ) $\left(\varepsilon=14 \mathrm{mM}^{-1} \mathrm{~cm}^{-1}\right)$.

\subsection{Statistical Analysis}

All data were subjected to one-way ANOVA and Tukey's multiple comparison test by using the Minitab statistical software package (Penn State University Park, State College, PA, USA, 2017). The data in the figures represent the means of three biological repeats and three technical replicates $\pm S D$. Different letters indicate significant differences between the two species and the time points at $p<0.05$.

\section{Conclusions}

Rice and barley belong to the same plant family but significantly differ in their metabolic processes activity, driving the subsequent germination steps. The embryos of rice seeds possess higher alcohol dehydrogenase activity, indicating more efficient anaerobic fermentation and elevated NO levels corresponding to higher NO turnover rates via the phytoglobin-NO cycle. Both fermentation and NO turnover result in a higher ATP / ADP ratio value in rice embryos prior to radicle protrusion, as compared to barley. The observed changes in seed metabolism following imbibition are due, in particular, to the differences in tolerance to the oxygen deficiency occurring under the seed coat. Radicle protrusion governs the subsequent transition to aerobic metabolism in the embryonic tissue. The balance and the crosstalk between NO, ROS and their scavengers determine the whole germination process under the oxygen depleted conditions of the imbibed seeds and upon aeration after radicle protrusion at the stage of seedling development.

Author Contributions: Conceptualization, A.U.I., N.V.B. and J.J.; methodology, A.U.I., N.V.B., J.J. and M.K.P.S.W.; software, J.J.; validation, A.U.I. and M.K.P.S.W.; formal analysis, J.J.; investigation, A.U.I. and J.J.; resources, A.U.I.; writing—original draft preparation, J.J. and M.K.P.S.W.; writing—review and editing, A.U.I., N.V.B., J.J. and M.K.P.S.W.; supervision, A.U.I. and N.V.B.; funding acquisition, A.U.I. and N.V.B. All authors have read and agreed to the published version of the manuscript.

Funding: This research was funded by the Natural Sciences and Engineering Research Council of Canada (NSERC), grant number RGPIN-2021-02945 (to A.U.I.), and by Agriculture and Agri-Food Canada, AAFC Project J-002600 (to N.V.B.).

Institutional Review Board Statement: Not applicable.

Informed Consent Statement: Not applicable.

Data Availability Statement: The datasets generated for this study are available upon request from the corresponding author. 
Acknowledgments: The authors express their gratitude to Mihiran M. Upeksha, Somaieh Zafari and Juran C. Goyali for their support of this study.

Conflicts of Interest: The authors declare no conflict of interest regarding the publication of this paper.

\section{References}

1. Hockett, E.A.; Nilan, R.A. Genetics. In Barley; Rasmusson, D.C., Ed.; American Society of Agronomy: Madison, WI, USA, 1985; pp. 187-230.

2. He, D.; Wang, Q.; Wang, K.; Yang, P. Genome-Wide Dissection of the MicroRNA Expression Profile in Rice Embryo during Early Stages of Seed Germination. PLOS ONE 2015, 10, e0145424. [CrossRef]

3. Perata, P.; Guglielminetti, L.; Alpi, A. Mobilization of endosperm reserves in cereal under anoxia. Ann. Bot. 1997, 79, 49-56. [CrossRef]

4. Bewley, J.D. Seed germination and dormancy. Plant Cell 1997, 9, 1055-1066. [CrossRef] [PubMed]

5. Hasanuzzaman, M.; Kamrun, N.; Masayuki, F. Plant response to Salt Stress and Role of Exogenous Protectants to Mitigate Salt-Induced Damages. In Ecophysiology and Responses of Plant under Salt Stress; Ahmad, P., Azooz, M.M., Prasad, M.N.V., Eds.; Springer: New York, NY, USA, 2013; pp. 25-87. [CrossRef]

6. Bewley, J.D.; Bradford, K.J.; Hilhorst, H.W.M.; Nonogaki, H. Seeds: Physiology of Development, Germination and Dormancy; Springer: New York, NY, USA, 2013. [CrossRef]

7. Mwami, B.M.; Nguluu, S.N.; Kimiti, J.M.; Kimatu, J.N. Effects of water imbibition of selected bean varieties on germination. Int. J. Innov. Sci. Res. Technol. 2017, 3, 57-62.

8. Bewley, J.D.; Black, M. Physiology of Development and Germination, 2nd ed.; Plenum Press: New York, NY, USA, $1994 ; 445$ p.

9. Nonogaki, H. Seed germination and dormancy: The classic story, new puzzles, and evolution. J. Integr. Plant Biol. 2019, 61, 541-563. [CrossRef] [PubMed]

10. Nutbeam, A.R.; Duffus, C.M. Oxygen exchange in the pericarp green layer of immature cereal grains. Plant Physiol. 1978, 62, 360-362. [CrossRef] [PubMed]

11. Borisjuk, L.; Rolletschek, H. The oxygen status of the developing seed. New Phytol. 2009, 182, 17-30. [CrossRef]

12. Larson, L.A. The effect of soaking pea seeds with or without seedcoats has on seedling growth. Plant Physiol. 1968, 43, 255-259. [CrossRef] [PubMed]

13. Bykova, N.V.; Hoehn, B.; Rampitsch, C.; Hu, J.; Stebbing, J.A.; Knox, R. Thiol redox-sensitive seed proteome in dormant and non-dormant hybrid genotypes of wheat. Phytochemistry 2011, 72, 1162-1172. [CrossRef]

14. Davies, D.D. Anaerobic metabolism and the production of organic acids. In The Biochemistry of Plants; Davies, D.D., Ed.; Academic Press: London, UK, 1980; Volume 2, pp. 581-611.

15. Kennedy, R.A.; Rumpho, M.E.; Fox, T.C. Anaerobic metabolism in plants. Plant Physiol. 1992, 100, 1-6. [CrossRef]

16. Gibbs, J.; Greenway, H. Mechanisms of anoxia tolerance in plants. I. Growth, survival and anaerobic catabolism. Funct. Plant Biol. 2003, 30, 999-1036. [CrossRef]

17. Duff, S.M.G.; Guy, P.A.; Nie, X.; Durnin, D.C.; Hill, R.D. Hemoglobin expression in germinating barley. Seed Sci. Res. 1998, 8, 431-436. [CrossRef]

18. Logan, D.C.; Millar, A.H.; Sweetlove, L.J.; Hill, S.A.; Leaver, C.J. Mitochondrial biogenesis during germination in maize embryos. Plant Physiol. 2001, 125, 662-672. [CrossRef] [PubMed]

19. Bethke, P.C.; Gubler, F.; Jacobsen, J.V.; Jones, R.L. Dormancy of Arabidopsis seeds barley grains can be broken by nitric oxide. Planta 2004, 219, 847-855. [CrossRef] [PubMed]

20. Bailly, C.; El-Maarouf-Bouteau, H.; Corbineau, F. From intracellular signaling networks to cell death: The dual role of reactive oxygen species in seed physiology. C. R. Biol. 2008, 331, 806-814. [CrossRef] [PubMed]

21. Oracz, K.; El-Maarouf-Bouteau, H.; Kranner, I.; Bogatek, R.; Corbineau, F.; Bailly, C. The mechanisms involved in seed dormancy alleviation by hydrogen cyanide unravel the role of reactive oxygen species as key factors of cellular signaling during germination. Plant Physiol. 2009, 150, 494-505. [CrossRef] [PubMed]

22. Wulff, A.; Oliveira, H.C.; Saviani, E.E.; Salgado, I. Nitrite reduction and superoxide-dependent nitricoxidedegradation by Arabidopsis mitochondria: Influence of external NAD $(\mathrm{P}) \mathrm{H}$ dehydrogenases and alternative oxidase in the control of nitric oxide levels. Nitric Oxide 2009, 21, 132-139. [CrossRef]

23. Tai, L.; Wang, H.J.; Xu, X.J.; Sun, W.H.; Ju, L.; Liu, W.T.; Li, W.Q.; Sun, J.; Chen, K.M. Cereal pre-harvest sprouting: A global agricultural disaster regulated by complex genetic and biochemical mechanisms. J. Exp. Bot. 2021, 72, 2857-2876. [CrossRef]

24. Kranner, I.; Minibayeva, F.V.; Beckett, R.P.; Seal, C.E. What is stress? Concepts, definitions and applications in seed science. New Phytol. 2010, 188, 655-673. [CrossRef]

25. Bykova, N.V.; Hoehn, B.; Rampitsch, C.; Bykova, N.V.; Hoehn, B.; Rampitsch, C.; Banks, T.; Stebbing, J.-A.; Fan, T.; alKnox, R. Redox-sensitive proteome and antioxidant strategies in wheat seed dormancy control. Proteomics 2011, 11, 865-882. [CrossRef]

26. Bykova, N.V.; Hu, J.; Ma, Z.; Igamberdiev, A.U. The Role of Reactive Oxygen and Nitrogen Species in Bioenergetics, Metabolism and Signaling during Seed Germination. In Reactive Oxygen and Reactive Nitrogen Species Signaling and Communication in Plants; Gupta, K.J., Igamberdiev, A.U., Eds.; Springer: Berlin, Germany, 2015; pp. 177-195. [CrossRef] 
27. Debska, K.; Krasuska, U.; Budnicka, K.; Bogatek, R.; Gniazdowska, A. Dormancy removal of apple seeds by cold stratification is Associated with fluctuation in $\mathrm{H}_{2} \mathrm{O}_{2}$, NO production and protein carbonylation level. J. Plant Physiol. 2013, 170, 480-488. [CrossRef] [PubMed]

28. Colville, L.; Kranner, I. Desiccation tolerant plants as model systems to study redox regulation of protein thiols. Plant Growth Regul. 2010, 62, 241-255. [CrossRef]

29. Davies, M.J.; Fu, S.; Wang, H.; Dean, R.T. Stable markers of oxidant damage to proteins and their application in study of human disease. Free Radic. Biol. Med. 1999, 27, 1151-1161. [CrossRef]

30. Møller, I.M.; Jensen, P.E.; Hansson, A. Oxidative modifications to cellular components in plants. Annu Rev Plant Biol. 2007, 58, 459-481. [CrossRef] [PubMed]

31. De Gara, L.; de Pinto, M.C.; Arrigoni, O. Ascorbate synthesis and ascorbate peroxidase activity during the early stage of wheat germination. Physiol Plant. 1997, 100, 894-900. [CrossRef]

32. Tommasi, F.; Paciolla, C.; de Pinto, M.C.; De Gara, L. A comparative study of glutathione and ascorbate metabolism during germination of Pinus Pinea L. seeds. J. Exp Bot. 2001, 52, 1647-1654. [CrossRef]

33. Müller, K.; Job, C.; Belghazi, M.; Job, D.; Leubner-Metzger, G. Proteomics reveal tissue-specific features of the cress (Lepidium sativum L.) endosperm cap proteome and its hormone-induced changes during seed germination. Proteomics 2010, 10, 406-416. [CrossRef]

34. Ma, Z.; Marsolais, F.; Bernards, M.A.; Sumarah, M.W.; Bykova, N.V.; Igamberdiev, A.U. Glyoxylate cycle and metabolism of organic acids in the scutellum of barley seeds during germination. Plant Sci. 2016, 248, 37-44. [CrossRef] [PubMed]

35. Ma, Z.; Marsolais, F.; Bykova, N.V.; Igamberdiev, A.U. Nitric Oxide and Reactive Oxygen Species Mediate Metabolic Changes in Barley Seed Embryo during Germination. Front. Plant Sci. 2016, 7, 138. [CrossRef]

36. Nonogaki, H.; Bassel, G.W.; Bewley, J.D. Germination-stillamystery. Plant Science 2010, 179, 574-581. [CrossRef]

37. Gruwel, M.L.H.; Chatson, B.; Yin, X.S.; Abrams, S.R. A magnetic resonance study of water uptake of whole barley kernels. Int. J. Food Sci. Technol. 2001, 36, 161-168. [CrossRef]

38. Yang, P.; Li, X.; Wang, X.; Chen, H.; Chen, F.; Shen, S. Proteomic analysis of rice (Oryza sativa) seeds during germination. Proteomics 2007, 7, 3358-3368. [CrossRef]

39. Geigenberger, P. Response of plant metabolism to too little oxygen. Curr. Opin. Plant Biol. 2013, 6, 247-256. [CrossRef]

40. Rolletschek, H.; Weschke, W.; Weber, H.; Wobus, U.; Borisjuk, L. Energy state and its control on seed development: Starch accumulation is associated with high ATP and steep oxygen gradients within barley grains. J. Exp. Bot. 2004, 55, 1351-1359. [CrossRef] [PubMed]

41. Weber, H.; Borisjuk, L.; Wobus, U. Molecular physiology of legume seed development. Annu. Rev. Plant Biol. 2005, 56, 253-279. [CrossRef]

42. He, D.; Yang, P. Proteomics of rice seed germination. Front. Plant Sci. 2013, 4, 246. [CrossRef] [PubMed]

43. Benamar, A.; Tallon, C.; Macherel, D. Membrane integrity and oxidative properties of mitochondria isolated from imbibing pea seeds after priming or accelerated ageing. Seed Sci. Res. 2003, 13, 35-45. [CrossRef]

44. He, D.; Han, C.; Yang, P. Gene expression profile changes in germinating rice. J. Integr. Plant Biol. 2011, 53, 835-844. [CrossRef]

45. Igamberdiev, A.U.; Hill, R.D. Nitrate, $\mathrm{NO}$ and haemoglobin in plant adaptation to hypoxia: An alternative to classic fermentation pathways. J. Exp. Bot. 2004, 55, 2473-2482. [CrossRef]

46. Zafari, S.; Hebelstrup, K.H.; Igamberdiev, A.U. Transcriptional and metabolic changes associated with phytoglobin expression during germination of barley seeds. Int. J. Mol. Sci. 2020, 21, 2796. [CrossRef]

47. Cakmak, I.; Strbac, D.; Marschner, H. Activities of hydrogen peroxide scavenging enzymes in germinating wheat seeds. J. Exp. Bot. 1993, 44, 127-132. [CrossRef]

48. Caliskan, M.; Cuming, A.C. Spatial specificity of $\mathrm{H}_{2} \mathrm{O}_{2}$-generating oxalate oxidase gene expression during wheat embryo germination. Plant J. 1998, 15, 165-171. [CrossRef] [PubMed]

49. Wojtyla, Ł.; Garnczarska, M.; Zalewski, T.; Bednarski, W.; Ratajczak, L.; Jurga, S. A comparative study of water distribution, free radical production and activation of antioxidative metabolism in germinating pea seeds. J. Plant Physiol. 2006, 163, 1207-1220. [CrossRef] [PubMed]

50. Gupta, K.J.; Igamberdiev, A.U. The anoxic plant mitochondrion as a nitrite: NO reductase. Mitochondrion 2011, 11, 537-543. [CrossRef]

51. Nie, X.Z.; Hill, R.D. Mitochondrial respiration and hemoglobin gene expression in barley aleurone tissue. Plant Physiol. 1997, 114, 835-840. [CrossRef]

52. Hunt, P.W.; Watts, R.A.; Trevaskis, B.; Llewelyn, D.J.; Burnell, J.; Dennis, E.S.; Peacock, W.J. Expression and evolution of functionally distinct hemoglobin genes in plants. Plant Mol. Biol. 2001, 47, 677-692. [CrossRef]

53. Ross, E.J.H.; Shearman, L.; Mathiesen, M.; Zhou, Y.J.; Arredondo-Peter, R.; Sarath, G.; Klucas, R.V. Nonsymbiotic hemoglobins in rice are synthesized during germination and in differentiating cell types. Protoplasma 2001, 218, 125-133. [CrossRef]

54. Kumari, A.; Singh, P.; Kaladhar, V.C.; Bhatoee, M.; Paul, D.; Pathak, P.K.; Gupta, K.J. Phytoglobin-NO cycle and AOX pathway play a role in anaerobic germination and growth of deepwater rice. Plant Cell Environ. 2021. [CrossRef]

55. Corpas, F.J.; Alché, J.D.; Barroso, J.B. Current overview of S-nitrosoglutathione (GSNO) in higher plants. Front. Plant Sci. 2013, 4, 126. [CrossRef] 
56. El-Maarouf-Bouteau, H.; Bailly, C. Oxidative signaling in seed germination and dormancy. Plant Signal. Behav. 2008, 3, 175-182. [CrossRef] [PubMed]

57. Kubala, S.; Wojtyla, Ł.; Quinet, M.; Lechowska, K.; Lutts, S.; Garnczarska, M. Enhanced expression of the proline synthesis gene P5CSA in relations to seed osmopriming improvement of Brassica napus germination under salinity stress. J. Plant Physiol. 2015, 183, 1-12. [CrossRef] [PubMed]

58. Anjum, N.A.; Sharma, P.; Gill, S.; Hasanuzzaman, M.; Khan, E.A.; Kachhap, K.; Mohamed, A.; Thangavel, P.; Devi, G.D.; Vasudhevan, P.; et al. Catalase and ascorbate peroxidase-representative $\mathrm{H}_{2} \mathrm{O}_{2}$-detoxifying heme enzymes in plants. Environ. Sci. Pollut. Res. Int. 2016, 23, 19002-19029. [CrossRef] [PubMed]

59. Guha, T.; Das, H.; Mukherjee, A.; Kundu, R. Elucidating ROS signaling networks and physiological changes involved in nanoscale zero valent iron primed rice seed germination sensu stricto. Free Radic. Biol. Med. 2021, 171, 11-25. [CrossRef]

60. Al-Mudaris, M. Notes on various parameters recording the speed of seed germination. Der Trop. 1998, 99, 147-154.

61. Blandino, A.; Caro, I.; Cantero, D. Comparative study of alcohol dehydrogenase activity in flor yeast extracts. Biotechnol. Lett. 1997, 19, 651-654. [CrossRef]

62. Joshi, A.K.; Ahmed, S.; Ames, G.F.L. Energy coupling in bacterial periplasmic transport systems. J. Biol. Chem. 1989, 264, 2126-2133. [CrossRef]

63. Yuroff, A.S.; Sabat, G.; Hickey, W.J. Transporter-mediated uptake of 2-chloro- and 2-hydroxybenzoate by Pseudomonas huttiensis strain D1. Appl. Environ. Microbiol. 2003, 69, 7401-7408. [CrossRef]

64. Murphy, M.M.; Noack, E. Nitric oxide assay using hemoglobin method. Methods Enzymol. 1994, 233, 240-250. [CrossRef]

65. Cochrane, D.W.; Shah, J.K.; Hebelstrup, K.H.; Igamberdiev, A.U. Expression of phytoglobin affects nitric oxide metabolism and energy state of barley plants exposed to anoxia. Plant Sci. 2017, 265, 124-130. [CrossRef]

66. Sakamoto, M.; Ueda, H.; Morikawa, H. Arabidopsis glutathione-dependent formaldehyde dehydrogenase is an Snitrosoglutathione reductase. FEBS Lett. 2002, 515, 20-24. [CrossRef]

67. Bradford, M.M. A rapid and sensitive method for the quantification of microgram quantities of protein utilizing the principle of protein-dye binding. Anal. Biochem. 1976, 72, 248-254. [CrossRef]

68. Velikova, V.; Yordanov, I.; Edreva, A. Oxidative stress and some antioxidant systems in acid rain-treated bean plants. Plant Sci. 2000, 151, 59-66. [CrossRef]

69. Tammela, P.; Vaananen, P.S.; Lakso, I.; Hopia, A.; Vourela, H.; Nygrem, M. Tocopherols, tocotrienols and fatty acids as indicators of natural ageing in Pinus sylvestris seeds. Scand. J. Forest Res. 2005, 20, 378-384. [CrossRef]

70. Agarie, S.; Hanaoka, N.; Kubota, F.; Agata, W.; Kaufman, B. Measurement of cell membrane stability evaluated by electrolyte leakage as a drought and heat tolerance test in rice (Oryza sativa L.). J. Fac. Agr. Kyushu Univ. 1995, 40, 233-240. [CrossRef]

71. Heath, R.L.; Parker, L. Photoperoxidation in isolated chloroplasts. I. Kinetics and stoichiometry of fatty acid peroxidation. Arch Biochem. Biophys. 1968, 125, 189-198. [CrossRef]

72. Beauchamp, C.; Fridovich, I. Superoxide dismutase: Improved assays and assay applicable to acrylamide gels. Anal. Biochem. 1971, 44, 276-278. [CrossRef]

73. Guilbault, G.G. Glucose Oxidase. In Handbook of Enzymatic Methods of Analysis; Schwartz, M.K., Ed.; Marcel Dekker: New York, NY, USA, 1976; pp. 106-109. 